\title{
Parvovirus Infection in a Child Complicated with Diabetic Ketoacidosis and Acute Fulminant Hepatitis: a Case Report
}

\section{Pediatrik Bir Hastada Diyabetik Ketoasidoz ve Akut Fulminan Hepatit ile Komplike Olan Parvovirüs Enfeksiyonu: Olgu Sunumu}

\author{
Beray Selver Eklioğlu', Mehmet Emre Atabek', Nesibe Akyürek², Meltem Gümüş ${ }^{3}$ \\ ${ }^{1}$ Necmettin Erbakan University School of Medicine, Department of Child Endocrinology, Konya, Turkey \\ ${ }^{2}$ Health Sciences University, Konya Training and Research Hospital, Clinic of Pediatric Endocrinology, Konya, Turkey \\ ${ }^{3}$ Health Sciences University, Konya Training and Research Hospital, Clinic of Pediatric Gastroenterology, Konya, Turkey
}

\begin{abstract}
Type 1 diabetes mellitus (T1DM) results from the destruction of pancreatic beta cells. Genetic and environmental factors are believed to be the major component for the development of the disease. Viruses have been suspected to contribute to the onset of T1DM. In this case report, a patient who had diabetic ketoacidosis with acute fulminant hepatitis following asymptomatic infection with parvovirus B19 virus (PB19) is presented. To our knowledge this is the first report of diabetic ketoacidosis (DKA) and acute fulminan hepatitis due to PB19. We suggest close monitoring of the liver functions in DKA and taking care when the liver functions deteriorate.
\end{abstract}

Keywords: Acute fulminan hepatitis, parvovirus, diabetic ketoacidosis, hypoglycemia

\section{Introduction}

Infection with parvovirus is very common and occurs worldwide. Acquisition is often during childhood and continues at lower rates throughout adulthood. Infectivity is more common in winter and spring. The clinical spectrum of the disorder is variable. Beside known outcomes, hepatitis and acute liver failure can develop (1). Diabetic ketoacidosis
Tip 1 diabetes mellitus (T1DM) pankreatik beta hücrelerinin harabiyeti ile ortaya çıkmaktadır. Genetik ve çevresel faktörlerin hastalığın gelişimindeki ana faktörler olduğu düşünülmektedir. Virüslerin hastalığın başlangıcında etkili olduğu düşünülmektedir. Bu olguda asemptomatik parvovirus B19 (PB19) enfeksiyonunu takiben ortaya çıkan diyabetik ketoasidoz ve akut fulminan hepatit birlikteliğinin olduğu bir olgu sunulmuştur. Diyabetik ketoasidozda karaciğer enzimlerinin de yakın izlenmesini ve kötüleşme olduğunda dikkat edilmesini önermekteyiz.

Anahtar Kelimeler: Akut fulminan hepatit, parvovirus, diyabetik ketoasidoz, hipoglisemi

(DKA) is a rare complication of diabetes mellitus. There is an increase of ketone bodies due to lipolysis. Ketone body accumulation leads to acidosis. The acidosis state of DKA could cause multiple organ failure and is a threat to human life (2) . In this report, a patient with type 1 diabetes mellitus (T1DM) and DKA who also had fulminant acute hepatitis triggered by PB19 is presented. In order for the treatment to be successful, close clinical and biochemical follow-up was required.
Correspondence Address / Yazışma Adresi

Beray Selver Eklioğlu

Necmettin Erbakan Üniversitesi Tıp Fakültesi, Çocuk Endokrinolojisi Bilim Dalı, Konya-Türkiye

E-mail: berayselver@hotmail.com
(C) Copyright 2017 by Pediatric Infectious Diseases Society -Available online at www.cocukenfeksiyon.org ○Telif Hakkı 2017 Çocuk Enfeksiyon Hastalıkları Derneği -Makale metnine www.cocukenfeksiyon.org web sayfasından ulaşılabilir 


\section{Case Reports}

The patient who was a 9 years 9 months old boy was admitted to the hospital with complaints of polyuria, polydipsia, decreased appetite and hyperglycemia for two days. His medical history was nonspecific. There was no record of transfusion. He also had hypoglycemia episodes as well as hyperglycemia for one week. He has been followed with T1DM for 3 years. In physical examination vital findings were normal. The patient's weight was $24.5 \mathrm{~kg}(-1.48 \mathrm{SDS})$ and his height was $133.2 \mathrm{~cm}(-0.56 \mathrm{SDS})$. Body mass index was $13.81 \mathrm{~kg} / \mathrm{m}^{2}$ (-1.95SDS). He had second degree dehydratation signs. The liver was palpable $4 \mathrm{~cm}$ in the right hypochondrium, but it was smooth and non-tender. There was $3 \mathrm{~cm}$ splenomegaly. Other systemic signs were normal. Blood gas analysis showed a pH of 7.29 and $\mathrm{HCO}_{3} 11 \mathrm{mmol} / \mathrm{L}$, blood ketone was $2+$. The patient was diagnosed as DKA and appropriate fluid-electrolyte and insulin therapy were started. Complete blood count showed white blood cell (WBC) $3331 / \mathrm{mm}^{3}$, neutrophil $756 / \mathrm{mm}^{3}$, lymphocytes $2240 / \mathrm{mm}^{3}, \mathrm{Hb} 11 \mathrm{~g} / \mathrm{dL}$, and platelets: $200.000 / \mathrm{mm}^{3}$. Biochemical findings revealed increased hepatic enzyme levels. Aspartate transaminase (AST) was $274 \mathrm{IU} / \mathrm{L}$, alanine transaminase (ALT) was $206 \mathrm{IU} / \mathrm{L}$ and kept rising later [AST 5653 IU/L, ALT 1523 IU/L); gamma glutamyl transferase (GGT) was $183 \mathrm{IU} / \mathrm{L}]$. In the coagulation profile International Normalized Ratio (INR) was 3.46, prothrombin time (PT) was $34.4 \mathrm{sec}$ and activated partial thromboplastin time (aPTT) was $40 \mathrm{sec}$. The patient had no hyperbilirubinemia and ammonia was $79 \mu \mathrm{g} /$ $\mathrm{dL}$ (31-123 $\mu \mathrm{g} / \mathrm{dL})$. He had hypoglycemia episodes beside hepatic enzyme increase. One week before hospitalization he had developed general fatigue and nausea. The patient did not exhibit autoantibodies, including antinuclear antibodies and antineutrophilic cytoplasmic antibodies. Ceruloplasmin was normal. Serology was negative for hepatitis A, B, C, E viruses, cytomegalovirus, Epstein-Barr virus, rubella virus, herpes virus, chlamydia, syphilis, mycoplasma, brucella, toxoplasma or human immunodeficiency virus but the PB19 was positive. The patient was diagnosed as acute hepatitis secondary to PB19 infection beside DKA. Insulin treatment, vitamin K, ursodeoxycholic acid and acetyl cysteine were administered. The patient's liver enzyme values gradually improved. On the $15^{\text {th }}$ day of hospitalization the patient's liver functions were normalized, hypoglycemia episodes were eliminated and he was discharged.

\section{Discussion}

The clinical spectra of disorders that are associated with PB19 infection is wide. The clinical spectrum includes erythema infectiosum, arthralgias and arthritis, transient aplastic crisis, also associations based on organ system. Hepatitis and fulminant liver failure can develop (1). Patients with impaired humoral immunity are at risk of chronic infections with parvovirus. Chronic anemia is the most common manifestation. Sometimes complete marrow supression occurs. Chronic infections are also seen in cytotoxic chemotherapy, in congenital immun deficiency on immunosupressive therapy and with IgG production defects (3). Temporary suppression of erythropoiesis during the viremic phase is usually well tolerated due to the long life span of erythrocytes, and hemoglobin levels remain fairly stable (4). Our patient had leukopenia and slightly low hemoglobin level and after one week leukopenia was cured.

Multiple factors are believed to involved in the development of T1DM. The virus may trigger beta cell-specific autoimmunity leading to diabetes, or may directly infect and destroy insulin-producing pancreatic beta cells, resulting in clinical T1DM (5). There is evidence associating T1DM with enterovirus infections in humans. These viruses promote a T-cell-mediated lymphoproliferative response that is dependent upon its presentation to CD4 cells by HLA class II antigens and could generate T-cell-mediated autoimmunity (6) Additionally, in infected children, prenatal rubella infection is associated with beta-cell autoimmunity up to $70 \%$ and with diabetes up to $40 \%$. However, intrauterine exposure to enteroviral infection is thought to be associated with beta-cell autoimmunity. Patients with autoimmunity may be more prone to enteroviral infection, may have a stronger humoral response to infection because of their particular HLA genotype, or may be in a nonspecific hyperimmune state marked by elevation of antibody levels to various exogenous antigens. Islet related autoantibodies have been found after various viral infections (7). In patients with T1DM, plasma insulin concentrations are determined by the rate of insulin administration and the rate of insulin clearance. The liver has a major role in insulin clearance as well as other aspects of glucose homeostasis. Patients with acute viral hepatitis have marked impairment of hepatic glycogen synthesis and a defect in gluconeogenesis. Such problems might have contributed to the hypoglycemia in this patient (8). Despite the insufficient data in literature, PB19 could be one of the triggers for DKA as well as acute hepatitis. Similarity of PB19 proteins and human proteins are thought to be related to the pathogenesis of autoimmune disorders triggered by this virus. Immunologic processes triggered by viral infection are considered as an etiological cause in the pathophysiology of fulminant T1DM (9).

The mechanism by which PB19 infection may result in hepatic injury is not clear. Hepatic manifestations of PB19 infection range from abnormal liver function tests to fulminant hepatic failure, especially in young children. Sokal et al. showed reported PB19 infection with fulminant hepatitis of unex- 
plained etiology (10). The main distinctive features are low bilirubin levels, high ALT and/or AST activity, and favorable outcome with rapid return to normal liver function without orthotopic liver transplantation. Rash, arthropathy and hematologic disturbances do not necessarily accompany fulminant hepatic failure (11). Acute hepatitis in association with PB19 infection has only rarely been reported in the literature (10). Díaz et al. described 2 patients with acute hepatitis (12). Both patients were positive for PB19. Two adult additional cases of PB19 associated hepatitis were reported by Hillings et al. (13). Also Sun and Zhang also reported hepatic dysfunction in an adult due to parvovirus (14). O'Brayan et al. found no association between parvovirus B19 and T1DM development in childhood (15). In this case, acute hepatitis was complicated with DKA. Our patient had an established biological diagnosis of PB19 primary infection with IgM positivity. Our patient's clinical course was appropiate with the findings in the literature. Although our patient developed acute fulminant hepatitis due to PB19, the outcome returned to normal liver function rapidly. The notion of PB19 virus as a causative agent of hepatic dysfunction has not been fully accepted. Associations have been proposed on the basis of the temporal association of symptoms in the context of serologic documentation of recent infection or detection of PB19 in peripheral blood or affected tissue (4).

In conclusion, we maintain that acute deterioration of liver functions by PB19 infection diminished insulin clearance and resulted in both insulinemia and hypoglycemia. Although PB19 infection can cause acute hepatitis, the role of parvovirus infection as a trigger of both hepatitis and DKA with hypoglycemia episodes has not been defined. To our knowledge ours is the first report of DKA and acute fulminant hepatitis due to PB19. We suggest close monitoring the liver functions in DKA and giving attention when the liver functions deteriorate.

Informed Consent: Oral approval was obtained from the relatives of the patient.

Peer-review: Externally peer-reviewed.

Author Contributions: Data and Processing - BSE, NA, MG; Academic Contribution in The Writing of Manuscript - BSE, MEA, NA.

Conflict of Interest: No conflict of interest was declared by the athors.

Financial Disclosure: The authors declared that this study has received no financial support.

\section{References}

1. Waldman M, Kopp JB. Parvovirus B19 and the kidney. Clin J Am SoC Nephrol 2007;2( Suppl 1):S47-56. [CrossRef]

2. Izumi K. Diabetic ketoacidosis with cytomegalovirus-associated colitis. Intern Med 2009;48:343-6. [CrossRef]

3. Kliegman RM. Parvovirus B19. Nelson Textbook of Pediatrics $18^{\text {th }}$ ed Chapter 218,1357-60.

4. Sun L, Zhang JC. Acute fulminant hepatitis with bone marrow failure in an adult due to parvovirus B19 infection. Hepatology 2012;55:329-30.

5. Jun HS, Yoon JW. A new look at viruses in type 1 diabetes. Diabetes Metab Res Rev 2003;19:8-31. [CrossRef]

6. van der Werf $N$, Kroese FG, Rozing J, Hillebrands JL. Viral infections as potential triggers of type 1 diabetes. Diabetes Metab Res Rev 2007;23:169-83. [CrossRef]

7. Agrawal M, Goel SP, Prakash A. Diabetic ketoacidosis following mumps. Indian Pediatr 2012;49:920-1. [CrossRef]

8. Gutiérrez-Grobe Y, Ponciano-Rodríguez G, Méndez-Sánchez N. Viral hepatitis infection and insulin resistance: a review of the pathophysiological mechanisms. Salud Publica Mex 2011;53:46-51. [CrossRef]

9. Nishiumi $T$, Okamoto $K$, Inamoto $S$, et al. Case of fulminant type 1 diabetes mellitus associated with parvovirus B19 infection. J Diabetes Investig 2014;5:472-3. [CrossRef]

10. Hatakka A, Klein J, He R, Piper J, Tam E, Walkty A. Acute hepatitis as a manifestation of parvovirus B19 infection. J Clin Microbiol 2011;49:3422-4. [CrossRef]

11. Ozçay F, Bikmaz YE, Canan O, Ozbek N. Hepatitis $A$ and parvovirus B19 infections in an infant with fulminant hepatic failure. Turk $J$ Gastroenterol 2006;17:148-50. [CrossRef]

12. Diaz F, Collazos J. Hepatic dysfunction due to parvovirus B19 infection. $\mathrm{J}$ Infect Chemother 2000;6:63-4. [CrossRef]

13. Hillingso JG, Jensen IP, Tom-Petersen L. Parvovirus B19 and acute hepatitis in adults. Lancet 1998;351:955-6. [CrossRef]

14. Sun L, Zhang JC. Acute fulminant hepatitis with bone marrow failure in an adult due to parvovirus B19 infection. Hepatology 2012;55:329-30. [CrossRef]

15. O'Brayan TA, Beck MJ, Demers $L M$, Naides SJ. Human parvovirus B19 infection in children with new onset Type 1 diabetes mellitus. Diabet Med 2005;22:1778-9. [CrossRef] 